\title{
Coming to discursive-deconstructive reading of gender equality
}

\author{
Ikävalko, Elina
}

2019-01-01

Ikävalko , E \& Brunila , K 2019 , ' Coming to discursive-deconstructive reading of gender equality ' , International Journal of Research and Method in Education , vol. 42 , no. 1 , pp. 33-45 . https://doi.org/10.1080/1743727X.2017.1413085

http://hdl.handle.net/10138/308568

https://doi.org/10.1080/1743727X.2017.1413085

unspecified

acceptedVersion

Downloaded from Helda, University of Helsinki institutional repository.

This is an electronic reprint of the original article.

This reprint may differ from the original in pagination and typographic detail.

Please cite the original version. 


\section{COMING TO DISCURSIVE-DECONSTRUCTIVE READING OF GENDER EQUALITY}

\section{Elina Ikävalko \& Kristiina Brunila}

ABSTRACT

Researchers often find themselves reflecting on either/or questions. This article examines the multiple discursive reality of gender equality, a topic comprising several juxtapositions connected to either/or thinking which also provide the topic its legitimacy. The examples come from the context of gender equality work and gender equality policy, which has been shaped in Finland by public bodies focused on equality, the Government and Government bodies, ministries, political parties, labour market organisations and NGOs, particularly the women's movement. Our aim was to establish a discursive-deconstructive reading that would allow us to move from either/or thinking to a both/and approach. This kind of approach enables to consider and acknowledge differences as cultural categorisations enabling to categorize and hierarchise people.

\section{INTRODUCTION}

The discursive-deconstructive reading we present in this article allows us to examine the functions of, and functioning in, social power relations. The reading can be used to examine the relationship between knowledge and power, the functions of power, and the relationship between power and agency in various contexts. By analysing discourses, we can analyse how "truths", normative ways of being and doing, as well as ideas about the right kind of knowledge and knowing, are produced and maintained and how they can be negotiated. In this article, we will present a way to apply the discursive-deconstructive approach. 
We as two critical scholars interested in power have not been interested about research just for the sake of it. In our research group of several researchers led by Kristiina Brunila we have been keen on writing something that is politically relevant, something that makes sense of this world and our thinking in terms of inequalities and education (Brunila 2016; Ikävalko 2016; Brunila et al. 2015). According to Michel Foucault $(1991,74)$ texts should not be considered universal truths, but propositions or openings for those who are interested in joining the game. Hence, we are not interested in seeking the exhaustive meanings of discourse or deconstruction or analysing the extensive, decades-long discussion on them. Rather, we are interested in how these concepts can be used in research on equality policy and what questions deconstruction can introduce to the examination of equality and education. We present some of the key perspectives and applications related to our reading and will illustrate them with examples from our research on equality policy and equality work (e.g., Brunila 2009; 2010; Ikävalko 2010). The discursive-deconstructive reading is not a strictly defined method, nor is it described in methodological guides that would explain how to use it.

Our examples will be limited in the areas of education policy and gender equality policy as well as to the recognition of the related power structures. We have, however, also applied this reading elsewhere to the analysis of power and agency (Brunila 2009, 2010; Ikävalko \& Brunila 2011). As in many Nordic countries, equality and social justice have been almost un-questioned goals of education in Finland. Even the neoliberal shift in educational policy discourses towards more efficient, accountable and labour market oriented education has not replaced equality as an important aspect of national education policy. (Gordon et al. 2003). With the help of discursivedeconstructive reading, it is possible to trouble the self-evident status of Finland as 'model counry of equality' and appreciation of gender equality in Finland. 
Gender equality work, which we understand as welfare work shaped by the market, welfare policy, and national and international funders (Brunila 2009), and gender equality policy have been shaped in Finland by public bodies focused on equality, the Government and Government bodies, ministries, parties, labour market organisations and NGOs, particularly the women's movement (e.g., Holli 2003; Pentikäinen 2002; Räsänen 2002). Similarly, many organisations and individuals have been involved in developing Finnish education policy, which is also analysed in this article because in Nordic countries education is considered central in promoting equality.

In this paper, we particulary explore the report on higher education and research policy commissioned by the Ministry of Social Affairs and Health and compiled by Kristiina Brunila in 2010. The report examines the Government's equality policy on science and higher education (1997-2008) as well as other key policies on science and higher education from the perspective of gender equality. Second, we investigate the discussions on equality in basic and secondary education, which took place in the early 2000s in conjunction with the reform of the Act on Equality between Women and Men. In addition, during 2004-2014 we have interviewed persons involved in long-term equality work as well as in equality policy and education policy. These policy documents together with interview data form an expansive description of the postitions and meanings of gender equality in Finnish education policy. The premise for our joint analysis was that equality and related gender issues together form a discourse called gender equality.

\section{INSPIRATION FROM THE FEMINIST POST-STRUCTURALIST RESEARCH}

Coming to discursive-deconstructive reading is inspired by our research on gender equality work and gender equality policy. Although approaches to gender equality work and the policies that steer it have occasionally been pitted against each other, they have primarily humanist and individualist 
orientations while also enhancing market-oriented aims such as efficiency and productivity (Brunila 2009; Ikävalko 2016). From this kind of an essentialist perspective, the individual has in turns been emancipated and addressed as the object of economic and job market interests:

When talking to long-term equality specialists they consistently told me how it was a battle, a fight, a constant negotiation to promote gender equality in market-oriented contexts. Discursive-deconstructive reading helped to argue that the better we understand the discursive production of subjectivity, the more options we have in understanding various forms of subjectivity and institutional settings that enforce equality. (Extract from a research diary)

To analyse policies related to gender equality together with tense position of individuals who make choices while being squeezed by economic constraints, we are suggesting a reading that recognises the forms of power that steer activities without being paralysed by them. We consider the discursive-deconstructive reading through feminist post-structuralist research (e.g., Butler 2006; 2016; Guttorm 2011; Davies 1993; Ikävalko 2016; Lather 2003; Naskali 2003; St. Pierre 2000). The research tradition we refer to applies and further develops the ideas of two philosophers, Michel Foucault and Jacques Derrida, while questioning the existence of a single, authentic reality. When the existence of several realities is acknowledged, it becomes impossible to find the absolute truth and unnecessary to seek it. Consequently, the fundamental strength of the discursive-deconstructive reading is that it considers reality or realities as produced and, hence, adjustable. This also means that science is not a privileged discourse that enables understanding, but only one world-creating discourse among others (Naskali 2004, 41). 
The deconstructive reading has previously been applied to some extent in research on education, particularly feminist research (e.g., Davies 1993; Lather 2003; Naskali 2003; St. Pierre 2000). The discursive (and partly deconstructive) approach with its variations has been popular in feminist research on politics (e.g., Bacchi 2000; Holli 2003; Kantola 2006; Lombardo et al. 2009; Lombardo and Forest 2012).

The discursive perspective entails the examination of power relations and the formation of the subject, whereas the deconstructive approach highlights the unnatural and conflicting nature of differences, which also has consequences for the formation of the subject. The notion of the relationship between knowledge and power as well as the idea of discourse as both regulating and productive (e.g., Foucault 1998) enable the simultaneous analysis of both social power relations that steer actions and agency, and the ways of acting in those power relations:

I came to think that equality work consists of sequences of repeated acts that solidify into the appearance of something that has been present all along. In other words, one who acts in equality work does not stand apart from the prevailing norms and conflicting power relations. No form of power has to be deterministic. (Extract from a research diary)

The discursive-deconstructive reading takes into account that although the practices that guide the exercise of power involve goals, agency does not disappear because the objects of power can recognise and change power relations (see also Alhanen 2007, 195-196; Rabinow 1984). This is useful to understand when studying activities such as gender equality work which is seeking to change something. Even though the speaker/agent is bound into using discursively constructed conventional language, the opportunity may arise to unbalance such discourses and question their 
compulsiveness (see Derrida 1988, 2003; also St. Pierre 2000, 493). Derrida has written about sous rature ("under erasure") to refer to unbalancing and undermining crossed out text as well as the signifiers, or their parts, that the text carries (also Hakala 2007). The deconstructive reading is characterised by overturning the binary pairs prevalent in all Western thought. Deconstruction is an analytical tool that can expose and dissect artificial oppositions, such as male/female, active/passive, inside/outside, heterosexual/homosexual or reason/emotion (e.g. Brunila \& Ikävalko 2012; Davies 1993).

The discursive-deconstructive reading focuses on both discursive power relations and the functioning in them, in other words, how the subject is formed. However, we must bear in mind that, as Rosi Braidotti has said, Foucault's and Derrida's approaches to the subject differ considerably from each other. For example, Derrida denied Foucault's idea of Western thought as the exclusion of madness (Braidotti 1993, 43). According to Foucault, Western history has primarily been a history of rationality based on the exclusion of the non-rational but, Derrida asked, if that is the case, can we, like Foucault, even try to conceive of a history that does not constantly repeat the violence associated with the exclusion of madness (ibid., 44). In addition, where Foucault emphasises the truth-value of theoretical utterances as well as their consequences (i.e., normativity and exclusions), Derrida prioritises the deconstruction of the connection between reason and history. Where Foucault deems that the origin of the subject lies in the exclusion of madness and, hence, the non-rational, Derrida considers this too as a phallogocentric belief in a whole presence, or an oneness that excludes another oneness. And where Foucault is interested in analysing the mechanisms of exclusion, Derrida concentrates on developing the potential for thought that would respect the principle of non-unity and non-presence (ibid., 47-48).

\section{COMING TO KEY CONCEPTS}


In the following section, we present four concepts central to the discursive-deconstructive reading: language, discourse, power and difference. The discursive-deconstructive reading is based on critical assumptions about knowledge and knowing that recognise the functions of power. This reading enables the analysis of knowledge, not as the pursuit of a single reality and a single truth, but as discursive and formed through language (Davies 1998; St. Pierre 2001).

The discursive-deconstructive reading is based on the idea that language produces and shapes reality. Another key concept for this reading is discourse, which is essentially linguistic but also surpasses language. Foucault believes that discourses represent historically, socially and institutionally changing and varying ways to define knowledge and truth. Discourse encompasses everything about which something can be said as well as everything that cannot be said (Foucault 2005). As Bacchi and Bonham clarify, " in Foucault the term 'discourse' refers to knowledge, what is "within the true", rather than to language. (...) The term 'discursive practice/s' describes those practices of knowledge formation by focusing on how specific knowledges ('discourses') operate and the work they do" (Bacchi \& Bonham 2014, 174).

We understand discourses are productive and formative, that is, they have material consequences. They are also dynamic. St. Pierre $(2000,485)$ has emphasised that rather than asking what discourse means, we should ask how it functions, how it is regulated and produced, what consequences it has and how it exists. Discourse provides some with the opportunity to become the subjects of utterances while rendering others into objects. Changes in discourses lead to changes in power. Dissenting is possible because discourses are not closed systems. Silences and peculiarities allow us to adjust discourses by making us find new conceptualisations and changing accepted truths (St. Pierre 2000, 485). 
The third key concept for the reading, which is closely related to language and discourse, is power. Foucault examined how power functions and with what consequences. He considered power to be simultaneously restricting and enabling. Power is omnipresent, but no one has exclusive rights or primary access to it. Foucault was interested in the subject, in the objectification of people into subjects (Foucault 1982, 778; 1998). He saw that power functioned best by concealing itself. For example, in Foucault's work Discipline and Punish: The Birth of the Prison (Surveiller et punir: Naissance de la prison, 1975/1977) power is connected to simultaneous objectification and subjectification. While the prisoners in Foucault's book were objectified into law breakers, they were also manipulated into obedience. In other words, placing oneself as the object of this form of power simultaneously enables subjecthood. (Foucault 1975/2000.)

Power functions in the subject in at least two ways: first, it makes the subject conceivable, creates the conditions of possibility (Foucault 1982). Second, power defines what becomes part of the subject's “own” actions. By recognising power, we can examine how we are simultaneously subjected to the conditions and learn to manage them "correctly" (Davies 1998; also Brunila 2009; Hakala 2007). The "correct" mastering and submission means repetition and the pleasure extracted from it, but it can also refer to discomfort and the recognition of the form of power.

However, because power easily conceals the conditions of the subject's formation, the subject begins to appear natural (e.g., Butler 2006; Davies 1998; Rabinow 1984). These conditions not only make the subject possible, but are also included in its formation. The conditions are rendered into existence through both the acts of formation and the acts of the subject that emerges from them (Butler 1997, 14). According to Butler, the actions of the subject depend on the norms that shape it, which means that the subject's continuity depends on how it can affect this shaping process. 
Agency is not, however, created by denying the shaping process; rather, that process opens possibilities for action. This means that agency is paradoxical, but not impossible. Regardless of its formation, the subject can take a critical distance to the norms that shape it and can assume that they are changeable. The subject then becomes somewhat "not known" and its existence is called into question because it does not embody norms in the sense that the subject would be fully recognised (Butler 2004, 3). In the case of gender, this may occur when the subject cannot be placed in a clear gender category or is placed in several categories at once. One example relates to the problems of binary gender in legislation and conceptions of parenthood for persons undergoing a process of female-to-male gender reassignment who become pregnant and cannot be placed unambiguously in the categories of man, woman or trans-man (see Vähäpassi 2012).

The fourth concept that affects our reading is social difference, which refers to the hierarchical categories produced through politics, culture and practices, such as age, gender, cultural background, social class, sexual orientation and gender identity or disability. Such differences take the form of binary pairs (e.g., Davies 1993; 1998). For example, it is easy to think of gender as a hierarchical and opposing difference between man and woman, cultural background as a difference between native Finn and foreigner, and sexual orientation as a difference between hetero- and homosexual. The discursive-deconstructive reading allows us to demonstrate the discursive nature and mutual dependency of such binary pairs as well as to make visible the construction of meaning as difference. Common opposites from the field of education and training include those of teacher/student, theory/practice, developer/target group, structure/agent and intellectual skills/manual skills. Other binary pairs include mind/body, white/black, adult/child and supervisor/subordinate. But why are these binaries problematic? Derrida (1978) says that they are violent because the illusion of their permanence and naturalness is always achieved at the expense of the "other", the one on the "wrong" side of the pair. Although it is difficult to eliminate such 
pairs entirely, we can strive to make visible what is silenced as a result of the quest for metaphysical permanence (Burman and MacLure 2005, 286). We cannot escape or deny the functioning of these binaries but we can emphasize their contingency and unnaturalness to open up space for change.

Judith Butler's (2004) theory of the formation of gender and sexuality is a good example of the application of the discursive-deconstructive reading. Butler claims that gender is about reiterated acts, which are not performed alone and are not the subject's "own". Instead, they take place together with others, who may also be fictional. The conditions which render gender into existence are independent of the subject, which means that the question of the agent or individual as the source of action is challenged. However, it does not mean that the construction of gender would be mechanical or automatic.

The discursive-deconstructive reading is political because it helps to highlight the contradictions of discourses and the related potential for change. This does not mean setting programmatic or reformist goals, replacing a compelling discourse with an equally compelling one, but rather demonstrating the frailty of the apparently self-evident and ideal differences and ways of being and doing, and showing how they require continuous reinforcement and upholding. In addition, we can perceive how easily such seemingly ancient binary pairs as the above-mentioned male/female category begin to disentangle and break down before our very eyes when we start to ask questions about their "foundations".

\section{Gender Equality As The Focus Of The Discursive-deconstructive ReAding}

When political processes and struggles for the achievement of gender equality are analysed in gender studies and political science, the content and meanings of gender equality are also seen as 
objects of continuous dispute (Bacchi 2000; Kantola 2006; Lombardo et al. 2009). Consequently, gender equality is not deemed to have any permanent or fundamental meaning, but to be shaped by time and place as well as the political objectives set for it. And because equality is not seen as having a fixed meaning, it remains open to change and challenges (Brunila 2009; Holli 2003; Lombardo et al. 2009). The struggle over the concept of gender equality is therefore an integral part of gender equality policy, and meanings ascribed to equality at any given time reorganise and transform social power relations by defining certain differences as more central for equality than others.

The reading presented here is similar to many of the discursive readings developed in research on gender equality policy (e.g., Bacchi 2009; Lombardo et al. 2009), but also contains some considerable differences. Like Lombardo et al. $(2009,9)$, we emphasise the significance of power relations in terms of both the opportunities for action available to those involved in gender equality policy and how the discursive reality of the time defines conceptions of equality. We also stress the importance of the observation that the instruments developed to promote gender equality (e.g., the mainstreaming of the gender perspective, equality planning or publicly funded projects) are not neutral, but rather contribute to producing meanings ascribed to equality (also, e.g., Rönnblom 2008). While such instruments may have unexpected and problematic consequences for equality, they may also open opportunities for action in other situations.

Moreover, the consequences of discourses are not governed by subjects and can also be unintended (Bacchi 2000). We do not examine discourses as intentional, or conscious attempts and strategic choices to shape reality (Forest and Lombardo 2012) because that perspective assumes an individual who makes rational choices, and reduces discourse to forms of speech and struggles for political meaning: 
It demands constant negotiations and constant recognizing of other people's opinions.

I have had to twist the words and turn the words and... (Extract from a long-term equality specialist interview).

However, the epistemological premise of our reading differs from certain other discursive conceptualisations of gender equality policy in that we see the discourse-shaping subject as being defined by discourses, which means that the subject cannot see beyond or outside its definition and simply "choose" the language he or she prefers (see Butler 1997). Gilles Deleuze (2010/1988) claims that Foucault was not interested in the personal aspect of language, but in the various localisations of the speaking subject and, in particular, the process of becoming a subject. This means, that we cannot analyse the speaker's "intention" from the consequences of a certain utterance; rather, those consequences are always connected to the wider political, discursive and historical "reality" in which the actions take place.

Therefore, we do not consider the subject to be a self-conscious, rational agent capable of profound "reflection" (cf. Bacchi 2009) on his or her own actions or, as suggested by Walby (2009), that the "best" justification for promoting gender equality can be arrived at through argumentation. Moreover, we do not believe that several simultaneous localisations lead to "mere" relativism and the impossibility of feminist politics (cf. ibid.). The deconstructive approach does not neutralise the effect of conflicting elements, but rather aims to preserve them and dismantle the idea of a coherent and consistent set of ideas (Naskali 2004, 40-41).

Another key difference relates to our way of conceptualising gender. Too often, research on equality policy takes the idea of binary gender as given, as a fact based on the male/female division, 
in which the binary categorisation is considered if not as a biological fact, then at least as a vitally important political premise. This being the case, feminism also appears as the promotion of women's status, and political action is called feminist depending on how it relates to this goal (cf., e.g., Lombardo et al. 2009). Connecting gender to other differences is seen to expand the concept of gender, and differences are kept in separate categories, which can, however, intersect with each other situationally or locally. In research, this may result in a world of pre-given, "ready-made" representations and not very surprising readings on gender. For us, the strength of the deconstructive-discursive reading (and the feminist policy based on it) is precisely that it demonstrates the unnaturalness of differences and does not maintain or strengthen the female/male categories under cover of feminist policy, but allows them to unravel.

The discursive-deconstructive analysis allows us to explore the forms of power related to gender equality together with their consequences. In this article, it means examining what can and cannot be said about gender equality in documents on equality policy and education policy. This is also why in the text we juxtaposed interviews of long-term equality specialists, research diary extracts and documents. The reading also addresses other questions, such as the nature of the discursive reality assumed in the research material, the contexts in which equality is mentioned, and the ways in which equality can be promoted. It is also important to note silences and absences, that which is not present or not said in the text. The discursive-deconstructive reading also means recognising how the questions the researcher asks of her material affect the research, in other words, how voices, perspectives and interests interact in the research.

When analysing documents on equality policy and education policy, other discourses should also be noted. In our research material, gender equality is located in a social situation dominated by economic thought. Our previous research has also examined how equality has been subjected to 
serving performance, efficiency and employment needs (Brunila 2009; Ikävalko \& Brunila 2011; also, e.g., Raevaara 2005). Our approach has enabled us to examine the practices, orders and institutions involved in producing discourses and knowledge together with their consequences relating to power. We have not only analysed the processes of producing discourses, but also demonstrated the ways in which discourses are practised, operationalised and supported institutionally, socially, economically and legislatively.

\section{LEGITIMITATION BY GENDER ELIMINATION}

You have to learn to neutralise it; you cannot have too many feeling there when you give your presentation; if you are able to present it very neutrally, and argue it, it goes through more easily. (Extract from a long-term equality specialist interview).

In Finland, gender equality politics have traditionally been based on planning and co-operation. Gender equality discourse, in turn, has been based on harmony of the two genders, and the idea that both women and men needed to advance gender equality (Kantola $\&$ al. 2012). The emphasis on social justice and co-operation - instead of gendered inequalities and conflict of interests - has in many cases removed a gender perspective from the equality discourse. This has had its consequences for gender equality policy as well; equality tends to be discussed in a gender-neutral way both in workplaces (Saari 2013) and in educational institutions (Ikävalko \& Kantola 2017).

As in many Nordic countries, equality has been almost un-questioned goal of education in Finland. Nevertheless the concept as well as gender equality work have received new instrumentalized and market-oriented meanings (Brunila et al. 2012; Gordon et al. 2003; Brunila 2009; Ikävalko 2016; Brunila et al. 2011). Officially, education and training have played a key role in promoting gender 
equality. The related equality work has been one of the most long-lasting areas of the Finnish Government's gender equality policy as well as of the equality efforts of various organisations. It has encompassed the projects for the deconstruction of gender roles launched by the education policy section of the Finnish Council for Gender Equality, established in the 1970s. I The promotion of equality in teacher education began in Finland in the 1980s with nationwide experimental projects, and Finnish universities undertook active efforts to promote equality in the 1990s as a result of the strengthening of women's studies and discussions on gender equality.

Gender equality has been the goal of Government programmes and equality programmes for some time now. The Government Programme of 2003-2007 states that gender equality will be mainstreamed throughout public administration. The methods used to assess gender impacts will be developed, and the assessment will be included in legislative drafting. The Government equality programme of 1997 specifies that equality will be promoted through the principle of mainstreaming. The Government equality programme of 2004-2007 sets out a commitment to assessing the equality impacts of legislation. The final report (2007) on the equality programme states that the promotion of equality is part of the performance and target steering of universities and universities of applied sciences (Brunila 2010).

However, the promotion of gender equality or the targets and measures in the above Government programmes and equality programmes did not affect general plans and programmes on science and higher education policy. With a few exceptions, no references could be found in the plans and programmes for research and higher education to the promotion of gender equality or connections to the targets and measures concerning science and higher education policy in the Government equality programmes. No targets or concrete measures to promote gender equality were included in policy documents on research and higher education. 
It always comes as a surprise that all of that really happens. That all those sort of clichés really come true. (Extract from a long-term equality specialist interview).

Two separate realities of equality policy and education policy have prevailed. Documents on research and higher education policy contained very few, if any, mentions of gender equality or equality in general, whereas Government programmes and the more concrete Government equality programmes presented gender equality as fairly advanced in the area of research and higher education policy.

Our research material also defined the status of equality in upper secondary education, this time in relation to the amendment of the Act on Equality between Women and Men. The memorandum of the committee preparing the amendment (Ministry of Trade and Industry 2002) defined equality problems in education largely from the perspective of the job market. In the memorandum, the gender segregation of fields of education is described as the primary equality problem in education. The memorandum notes that although projects have been established to prevent the gender segregation of elective school subjects, "the education system does not currently have the means to achieve the desired results" (ibid., 13). The committee also discussed the adoption of gender quotas to prevent educational segregation, but found that the Act on Equality between Women and Men should not be amended in this respect; rather, "to alleviate segregation, the foundations of curricula should be reformed to affect the content of education and the methods of teaching" (ibid.).

Equality is self-evidently considered part of education policy in documents on equality policy. In education policy, however, equality remains invisible: although the theme of gender equality has been discussed for years, related targets have proved difficult to transfer into documents related to 
higher education as well as into the plans of educational administration, which is responsible for basic and general education (e.g., Jakku-Sihvonen 2011). The problems of educational equality seemed most pertinent at the secondary level. Whereas equality is in an manner of speaking 'being handled' in the higher education sector and the need for equality efforts is contested in early childhood and basic education, the secondary education sector and, in particular, the gendered education choices made at that level are most widely considered to require equality policy efforts.

\section{THE Heteronormative Gender ORDER}

In the project, the female energy increased in a right way. (Extract from an equality project promoting equality in ICT-field).

One of the opportunities provided by the discursive-deconstructive reading relates to the content of the concept of gender, as produced through negotiations on equality and education, as well as to the consequences that these practices, which we call "heteronormative", may have for equality. In order to become funded and legitimised, equality work calls for heteronormativity (e.g. Brunila 2009). Heteronormativity carries the idea of a hierarchical gender order. It means a code of behaviour that expects women to behave in a less valued "feminine" manner, and men in a more valued "masculine" manner (see more in detail Lehtonen, 2010). In the Finnish society, projectisation, marketisation and heteronormativity have formed a vicious circle by benefiting each other and regulating how equality ought to be talked about in order to be heard. Projectisation combines the ideas of new governance and governmentality. As a form of new governance, it represents market-oriented, managerialist, self-organising networks, and by incorporating, producing and positioning everyone involved with project-based work it represents a form of governmentality (see Brunila 2011). 
They [the evaluators] had written that the objective of the project is to bring more women into the technology field. I then said that bringing women into the technology field never existed in the project plan. To my mind it has not been the aim of the project. The evaluator, however, continued arguing that it was the goal. (Extract from a long-term equality specialist interview).

The promotion of equality in education and training has taken many twists and turns in the past decades, but some themes, such as the elimination of educational segregation, have remained. The area of equality efforts that has received the most financial resources has involved encouraging women to apply for studies in engineering and technology; numerous projects in this area have received public funding in the past decades. Equality has also been promoted through gender-aware education, teaching, development and research as well as equality committees and plans (Brunila et al. 2005; Lahelma 2011; Sunnari 1997). And conversely, the increase in knowledge through education has been one of the key strategies for integrating equality perspectives into public decision-making and the activities of private companies because it has seemed an effortless and simple way to promote equality in a way that benefits everyone (Rönnblom 2008, 126).

The issues of heteronormative gender and gender diversity were excluded from reports on higher education policy. This had certain implications for who were and who were not affected by gender equality in the report. In the education policy documents we studied, the sections that referred to gender usually connected it to the hierarchical and oppositional gender order, or the idea that there are only two types of people in the world, girls and boys or women and men. The research questions of report were formulated in advance together with its commissioners and limited the "script" for exploring gender equality. 
The issues of educational equality addressed during the preparation of the reform of the Act on Equality between Women and Men included the poorer school performance and adjustment of boys (compared to girls) as well as sexual harassment at schools (Ministry of Trade and Industry 2002, 13). In addition, the memorandum highlighted education as one of the few social sectors in which women outperform men by having higher education levels (ibid., 17). The status of boys and men in education continuously arises in our research material. Other causes of concern include the exclusion of boys and men and the high number of female students in higher education. As a rule, pupils, students and teachers are described in the documents as abstract individuals stripped of social differences. Concerns about the educational performance of boys and men and the need for male role models have been raised in discussions on education and equality for several decades (see Arnesen et al. 2008; Lahelma 1992; Lahelma and Öhrn 2003).

However, the documents we analysed lacked a more detailed exploration of which boys and men were referred to in each individual context. The documents also disregarded the learning difficulties experienced by many girls, and the risk of exclusion affecting some girls. The hierarchical and oppositional gender order is an example of the power of discourse.

The sexual harassment discussion that occurred during the reform of the Act on Equality between Women and Men interestingly combined the attempt to blot out gender and sexuality with keeping gender equality perspectives outside the sphere of education. According to the committee preparing the reform, one of the problems of the Act at the time was that it did not include a ban on discrimination in the education sector or a related ban on harassment which would have been subject to a compensatory penalty. A similar requirement affecting vocational education had been in 
place since the adoption of Directive 2002/73/EC, which amended the previous Directive on the implementation of the principle of equal treatment for men and women.

For comprehensive and upper secondary schools, the reforms were justified with studies and reports which showed that sexual harassment is common in comprehensive schools. Consequently, the committee proposed that the ban on discrimination, including sexual and gender-based harassment and subject to a compensatory penalty, would be extended to cover not only the secondary level but also basic education. However, the committee representatives of employer and employee organisations submitted a dissenting opinion, according to which the ban on discrimination should apply only to vocational education. They justified their opinion as follows:

"The regulation would lead to a situation in which, for example, disputes between pupils would have to be resolved with reference to the Act on Equality between Women and Men. It would be necessary to assess whether disputes comply with the definition of sexual harassment under the Act. With the parties to such disputes being minors and sometimes even primary school children, the proposed regulation would be inappropriate and likely to associate equality with problems to which it is irrelevant. The Act on Equality between Women and Men is not the right instrument to resolve situations involving minors, and an emphasis on the ban on sexual harassment would be unnecessary and inappropriate. Harassment at an educational establishment is a serious matter which the establishment in question must address using the means available to it." (Ministry of Trade and Industry 2002, 138).

As Elina Ikävalko has noted elsewhere (2010), the employer and employee organisations cooperated with each other in drafting the Act and during the subsequent Parliament proceedings. 
Extending the ban on discrimination to educational establishments seemed difficult precisely because of the related ban on sexual harassment, which divided opinion particularly between labour market organisations and women's organisations.

Our reading allows us to make several interesting observations about the above extracts. First, the dissenting opinion points to concerns about adult legislators turning "disputes" between minors into suspiciously sexual incidents, a kind of tarnishing of children's innocence (cf. Jyränki and Kalha 2009). The assumption seems to be that children cannot be sexual and therefore abuse the power associated with sexuality. The text speaks neutrally about pupils, minors and primary school children, but does not connect bullying or harassment to gender or make clear who is affected. The assumption may also be that harassment is always heterosexual, meaning that it takes places between persons of two genders, girls and boys, in which the perpetrator and the victim can be clearly differentiated.

The heterosexual discourse on harassment and bans on sexual harassment often assumes that the perpetrator and the victim can be identified and that their gender can also be specified (cf. Naskali 2001). Women may be too easily declared victims, thereby defining the female subject as more passive than the male subject (also) in terms of sexuality and reinforcing yet another gender dichotomy (active/passive). When harassment is conceived of as a one-way process between individuals, the associated discursive power relations remain concealed and the situational, historical and political background to harassment goes unnoticed.

The importance of equality in education (and, to some extent, the existence of related problems) was noted several times during the reform of the Act on Equality between Women and Men, but opinions about the definition of equality and the measures to promote equality varied considerably 
(cf., e.g., Raevaara 2005). Despite attempts to keep education and gender equality policy apart during the reform, some also referred to education policy to justify why the amendment of the Act's provisions on education was unnecessary.

\section{DARE TO BE SUPRISED?}

In this article, we presented some of the key starting points of applying discursive-deconstructive reading and how we have applied it. Our intention was to make visible some of the effects of discursive power in terms of subjects and agency. By analysing discourses, we can analyse how "truths", normative ways of being and doing, as well as ideas about the right kind of knowledge and knowing, are produced and maintained and how they can be negotiated.

Based on our research, a crucial obstacle to the advancement of equality seems to be that the division into two results in assumptions about the fundamental dissimilarity of women and men - or vice versa. In the most extreme cases, women and men are seen as complementing each other in a manner whereby the two together form 'a complete human being'. The assumption of differing characteristics leads into different treatment, which then produces differences that strengthens the assumption of gender-bound characteristics (see also Brunila et. all 2005). As in the example of sexual harassment in schools, the heteronormative thinking assumes certain subjects as active and puts others automatically to the position of a victim.

We are going around in circles. However, it is possible to try and break the circle. With discursivedeconstructive reading we can look at differences such as gender as fictional, social and cultural construction situated within discursive practices. It also directs the attention of a researcher to look at the inequalities or hierarchies, which do not adhere to binary category of gender. This kind of 
approach enables to consider and acknowledge differences as cultural categorisations enabling to categorize and hierarchise people.

\section{REFERENCES}

Alhanen, Kai. 2007. Käytännöt ja ajattelu Michel Foucault'n filosofiassa [Practices and thought in Michel Foucault's philosophy]. Helsinki: Gaudeamus.

Arnesen, Anne-Lise, Lahelma, Elina, and Öhrn, Elisabet. 2008. “Travelling discourses on gender and education: the case of boys' underachievement”. Nordisk Pedagogik, 28(1): 1-14.

Bacchi, Carol. 2000. "Policy as discourse: what does it mean? Where does it get us?" Discourse: studies in the cultural politics of education, 21(1): 45-57.

Bacchi, Carol. 2009. "The issue of intentionality in frame theory: the need for reflexive framing". In The discursive politics of gender equality: stretching, bending, and policy-making edited by Emanuela Lombardo, Petra Meier and Mieke Verloo. London: Routledge.

Bacchi, Carol, and Bonham, Jennifer. 2014. "Reclaiming discursive practices as an analytic focus: Political implications". Foucault Studies 17: 173-192.

Braidotti, Rosi. 1993. Riitasointuja. [Patterns of Dissonance: an Essay on Women in Contemporary French Philosophy]. Tampere: Vastapaino.

Brunila, Kristiina. 2009. Parasta ennen. Tasa-arvotyön projektitapaistuminen. Helsingin yliopisto: Kasvatustieteen laitoksen tutkimuksia.

Brunila, Kristiina. 2010. Sukupuolten tasa-arvo korkeakoulutuksessa ja tutkimuksessa. Sosiaali- ja terveysministeriön selvityksiä 2009:51. Helsinki: Yliopistopaino.

Brunila, Kristiina, and Ikävalko, Elina. 2012. "Vallan tunnistaminen siihen lamaantumatta: näkökulmia diskursiivis-dekonstruktiiviseen lukutapaan”. Politiikka 54(4): 285-300. 
Brunila, Kristiina, and Ylöstalo, Hanna. 2015. "Challenging Gender Inequalities in Education and in Working Life - A Mission Possible?" Journal of education and work, 28(5): 443-460.

Brunila, Kristiina, and Edström, Charlotta. 2015. 'Troubling Equality. Revisiting Gender Equality Work in the Famous Nordic Model Countries”. Journal of Educational Change.

Brunila, Kristiina. 2016.’The Ambivalences of Becominga Professor in Neoliberal Academia”. Qualitative Inquiry, 22(5): 386-394.

Brunila, Kristiina, Heikkinen, Mervi and Hynninen, Pirkko. 2005. Monimutkaista mutta mahdollista. Hyviä käytäntöjä tasa-arvotyöhön. Oulun yliopisto, Kajaanin yliopistokeskus. Burman, Erica, and MacLure, Maggie. 2005. "Deconstruction as a method of research". In, Research methods in the social sciences edited by B. Somekh \& C. Lewin. London: Sage Publications.

Butler, Judith. 1997. The psychic life of power: Theories in subjection. Stanford, CA: Stanford University Press.

Butler, Judith. 2004. Undoing gender. New York, NY: Routledge.

Butler, Judith. 2006. Hankala sukupuoli: feminismi ja identiteetin kumous. [Gender trouble:

Feminism and the subversion of identity]. Helsinki: Gaudeamus.

Davies, Bronwyn. 1993. Shards of glass: children reading and writing beyond gendered identities. Cresskill, NJ: Hampton Press.

Davies, Bronwyn. 1998. A body of writing 1990-1999. Walnut Creek, CA: AltaMira Press. Deleuze, Gilles. 2010. Foucault. London: Continuum.

Derrida, Jacques. 1978. Of grammatology. Baltimore, MD: Johns Hopkins University Press. Derrida, Jacques. 1988. Positioita [Positions]. Helsinki: Gaudeamus.

Derrida, Jacques. 2003. Platonin apteekki ja muita kirjoituksia [Plato’s Pharmacy and other writings]. Helsinki: Gaudeamus. 
Forest, Maxime, and Lombardo, Emanuela. 2012. "The Europeanization of gender equality policies: a discursive-sociological approach". In The Europeanization of gender equality policies: a discursive-sociological approach edited by Emanuela Lombardo and Maxime Forest. Hampshire: Palgrave Macmillian.

Foucault, Michel. 1982. Afterword by Michel Foucault: “The Subject and Power”. In Michel Foucault: beyond structuralism and hermeneutics edited by H. Dreyfus and P. Rabinow. Brighton: The Harvester Press.

Foucault, Michel. 1991. "Questions of method”. In The Foucault effect: studies in governmentality with two lectures and an interview with Michel Foucault edited by G. Burchell, C. Gordon and P. Miller. Chicago, IL: University of Chicago Press.

Foucault, Michel. 1976/1998. Seksuaalisuuden historia: Tiedontahto, Nautintojen käyttö, Huoli itsestä [The History of Sexuality: The Will to Knowledge, The Use of Pleasure, The Care of the Self]. Helsinki, Finland: Gaudeamus.

Foucault, Michel. 1975/2000. Tarkkailla ja rangaista [Discipline and Punish: The Birth of the Prison]. Keuruu: Otava.

Foucault, Michel. 1969/2005. Tiedon arkeologia [The Archeology of Knowledge]. Tampere: Vastapaino.

Gordon, Tuula, Lahelma, Elina and Beach, Dennis. 2003. "Marketisation of demokratic education: Ethnographic insights". In Democratic education. Ethnographic challenges edited Dennis Beach, Tuula Gordon and Elina Lahelma. London: Tufnell Press, 1-9.

Guttorm, Hanna Ellen. 2012. "Becoming-(a)-paper, or an article undone: (post-)knowing and writing (again), nomadic and so messy". Qualitative Inquiry, 18(7): 595-605.

Hakala, Katariina. 2007. Paremmin tietäjän paikka ja toisin tietämisen tila. Opettajuus (ja tutkijuus) pedagogisena suhteena [The position of knowing better and the space for knowing otherwise. 
Pedagogical mode of address in teaching (and in research)] (Helsingin yliopisto. Kasvatustieteen laitoksen tutkimuksia 212). Helsinki: Helsinki University Press.

Hallitusohjelma 2003-2007. Anneli Jäätteenmäen ja Matti Vanhasen hallitusten ohjelmat [Government programmes of Prime Ministers Anneli Jätteenmäki and Matti Vanhanen]. Valtioneuvosto. Retrieved from http://valtioneuvosto.fi/tietoa/historiaa/hallitusohjelmat. Hallituksen tasa-arvo-ohjelma 1997-1999. Pekingistä Suomeen. Suomen hallituksen tasa-arvoohjelma [From Beijing to Finland. Finnish government action plan for gender equality]. Retrieved from http://pre20031103.stm.fi/suomi/hao/julkaisut/tasa97.htm.

Hallituksen tasa-arvo-ohjelma 2004-2007. Sosiaali- ja terveysministeriön julkaisuja 2005:1. Retrieved from http://www.stm.fi/julkaisut/nayta/-/_julkaisu/1060505.

Hallituksen tasa-arvo-ohjelman 2004-2007. Loppuraportti 2007.

Holli, Anne Maria. 2003. Discourse and politics for gender equality in late twentieth century Finland. Helsinki: Helsinki University Press.

Ikävalko, Elina. 2010. "Taistelu tiedosta. Tasa-arvolain uudistus vuosituhannen vaihteessa". Naistutkimus. 4/2010: 57-60.

Ikävalko, Elina, and Brunila, Kristiina 2011. 'Tasa-arvosuunnittelu managerialistisen hallinnan tekniikkana". Sosiologia 48:4, 323-337.

Ikävalko, Elina. 2016. Vaikenemisia ja vastarintaa. Valtasuhteet ja toiminnan mahdollisuudet oppilaitosten tasa-arvosuunnittelussa. Kasvatustieteellisiä tutkimuksia 270. Helsingin yliopisto. Ikävalko, Elina, and Kantola, Johanna. 2017. "Feminist resistance and resistance to feminism in gender equality planning in Finland”. European journal of women's studies 24(3): 233-248. Jakku-Sihvonen, Ritva. 2011. “Tasa-arvo opetushallinnon näkökulmasta” [Equality from the perspective of educational administration]. In Sukupuolinäkökulmia tutkimusperustaiseen opettajankoulutukseen edited by Jukka Lehtonen, 22-24 [Gender perspectives on research-based teacher education]. Helsinki: University of Helsinki. 
Jyränki, Julia, and Kalha, Harri. 2009. Tapaus Neitsythuorakirkko [The Case of the Church of the Virgin Whore]. Helsinki: Like.

Kantola, Johanna. 2006. Feminists theorize the state. New York, NY: Palgrave Macmillian.

Kantola, Johanna, Nousiainen, Kevät, and Saari, Milja .2012. (Eds). Tasa-arvo toisin nähtynä.

Oikeuden ja politiikan näkökulmia tasa-arvoon ja yhdenvertaisuuteen. Helsinki: Gaudeamus.

Lahelma, Elina. 1992. Sukupuolten eriytyminen peruskoulun opetussuunnitelmassa [The Separation of the Sexes in the Finnish High School System]. Research Report 132. Helsinki: University of Helsinki, Department of Education.

Lahelma, Elina. 2011. "Gender awareness in Finnish teacher education: an impossible mission?" Education Inquiry 2(2): 263-270.

Lahelma, Elina, and Öhrn, Elisabet. 2003. “Strong Nordic women in the making?” In Democratic education: ethnographic challenges edited by Dennis Beach, Tuula Gordon and Elina Lahelma. London: The Tufnell Press.

Lather, Patti. 2003. Applied Derrida: (Mis)Reading the work of mourning in educational research. Educational Philosophy and Theory 35(3): 257-270.

Lehtonen, Jukka. 2010. Gendered Post-Compulsory Educational Choices of Non-Heterosexual Youth. European Educational Research Journal 9(2): 177-191.

Lombardo, Emanuela and Forest, Maxime, eds. 2012. The Europeanization of gender equality policies: a discursive-sociological approach. Basingstoke: Palgrave Macmillian. Lombardo, Emanuela, Meier, Petra, and Verloo, Mieke. 2009. Stretching and bending gender equality: a discursive politics approach. In The discursive politics of gender equality: stretching, bending, and policy-making edited by Emanuela, Lombardo, Petra, Meier and Mieke Verloo. London: Routledge.

Ministry of Trade and Industry. 2002. Tasa-arvolain uudistamistoimikunnan mietintö 2002. Komiteamietintö 2002:9. Helsinki: Sosiaali- ja terveysministeriö. 
Naskali, Päivi. 2001. "Sukupuoli ja ruumiillisuus opetuksellisessa vuorovaikutuksessa" [Gender and corporeality in educational interaction]. Naistutkimus 14(3): 4-15.

Naskali, Päivi. 2003. ’Dekonstruktio uusien kysymysten avaajana kasvatustieteessä ja yliopistopedagogiikassa" [Deconstruction in educational research and in university pedagogy: Opening up new questions]. Kasvatus 34(1): 18-29.

Naskali, Päivi. 2004. ”Lukemista näkemättä, näkemistä lukematta: suomalaisen kasvatusfilosofian sukupuolineutraalius dekonstruktiivisen luennan valossa" [Reading without seeing, seeing without reading: the gender-neutrality of the Finnish educational philosophy from a deconstructive point of view]. Naistutkimus 17(2): 33-45.

Pentikäinen, Marja. 2002. ’Tasa-arvoperiaate ihmisoikeusperiaatteena. Kansainväliset ihmisoikeudet ja naiset - näkymättömästä näkyväksi ”[Equality principal as a human rights principal. International human rights and women - from invisible to visible]. In Tasa-arvopolitiikan haasteet [Challenges of equality politics] edited by Anne Maria, Holli, Terhi, Saarikoski and Elina, Sana. Porvoo: WSOY \& TANE Council for Gender Equality.

Rabinow, Paul, ed. 1984. Foucault reader. New York: Pantheon Books.

Raevaara, Eeva. 2005. Tasa-arvo ja muutoksen rajat: sukupuolten tasa-arvo poliittisena ongelmana Ranskan parité- ja Suomen kiintiökeskusteluissa [Equality and the limits of change: gender equality as a political dilemma in the parité discussions in France and discussions about quotas in Finland] (Tane-julkaisuja 7). Helsinki: TANE Council for Gender Equality. Ministry of Social Affairs and Health.

Räsänen, Leila. 2002. ”Hallituksen tasa-arvopolitiikkaa tekemässä” [Government equality politics in the making]. In Tasa-arvopolitiikan haasteet [Challenges of equality politics] edited by Anne Maria, Holli, Terhi, Saarikoski and Elina, Sana. Porvoo: WSOY \& TANE Council for Gender Equality. 
Rönnblom, Malin. 2008. "De-politicising gender? Constructions of gender equality in Swedish regional policy". In Critical studies of gender equalities: Nordic dislocations, dilemmas and contradictions edited by Eva, Magnusson, Malin, Rönnblom \& Harriet, Silius. Gothenburg: Makadam Publishers.

Saari, Milja. 2013. "Promoting Gender Equality without a Gender Perspective: Problem representations of equal pay by in Finland". Gender, Work and Organization 20(1): 36-55.

St. Pierre, Elizabeth Adams. 2000. "Poststructural feminism in education: an overview". International Journal of Qualitative Studies in Education 13(5): 477-515.

St. Pierre, Elizabeth Adams 2001. "Coming to theory: finding Foucault and Deleuze”. In Feminist engagements: reading, resisting, and revisioning male theorists in education and cultural studies edited by K. Weiler. London: Routledge.

Sunnari, Vappu. 1997. Gendered structures and processes in primary teacher education: challenge for gender-sensitive pedagogy. Oulu: University of Oulu.

Vähäpassi, Emmi. 2012. "Mediakohu synnyttävistä miehistä ja figuraation politiikka" [Media commotion on men giving birth and the politics of figuration]. Naistutkimus 25(3): 44-50. Walby, Sylvia. 2009. "Beyond the politics of location. The power of argument in gender equality politics". In The discursive politics of gender equality: stretching, bending, and policy-making edited by Emanuela, Lombardo, Petra, Meier, and Mieke Verloo. London: Routledge. 